\title{
Karyotype studies in Mimosa (Mimosoideae, Leguminosae) from Southern South America and ecological and taxonomic relationships
}

\author{
Morales Matías , Arturo F. Wulff , Renée H. Fortunato \& Lidia Poggio
}

To cite this article: Morales Matías , Arturo F. Wulff, Renée H. Fortunato \& Lidia Poggio (2011) Karyotype studies in Mimosa (Mimosoideae, Leguminosae) from Southern South America and ecological and taxonomic relationships, Caryologia, 64:2, 203-214, DOI: 10.1080/00087114.2002.10589785

To link to this article: https://doi.org/10.1080/00087114.2002.10589785

\section{曲 Published online: 10 Feb 2014.}

Submit your article to this journal

Шll Article views: 112

Q View related articles $₫$

4 Citing articles: 5 View citing articles 


\title{
Karyotype studies in Mimosa (Mimosoideae, Leguminosae) from Southern South America and ecological and taxonomic relationships
}

\author{
Morales Matías ${ }^{1,2 *}$, Arturo F. WulfF ${ }^{2,4}$, Renée H. Fortunato ${ }^{1,2,3}$ and Lidia Poggio ${ }^{2,4}$ \\ ${ }^{1}$ Facultad de Agronomía y Ciencias Agroalimentarias, Universidad de Morón: Cabildo 134, (B1708JPD), \\ Morón, Argentina. \\ ${ }^{2}$ CONICET (Argentina). \\ ${ }^{3}$ Instituto de Recursos Biológicos, CIRN-INTA (Hurlingham, Argentina), Las Cabañas y Los Reseros s/n (1686), \\ Hurlingham, Argentina. \\ ${ }^{4}$ Departamento de Ecología, Genética y Evolución, Facultad de Ciencias Exactas y Naturales, Universidad de \\ Buenos Aires, Intendente Güiraldes y Costanera Norte (CI42EHA), Buenos Aires, Argentina.
}

\begin{abstract}
In this work we studied the chromosome number and karyotype formula of seven species of Mimosa L. (Mimosoideae, Leguminosae). The chromosome number $2 \mathrm{n}=2 \mathrm{x}=26$ for $M$. detinens Benth., M. hexandra M. Micheli, M. ostenii Speg. ex Burkart and M. xanthocentra Mart. var. mansii (Benth.) Barneby are new records, while the chromosome number $2 \mathrm{n}=2 \mathrm{x}=26$ for M. debilis var. debilis, M. urugüensis Hook. and Arn. and M. uliginosa Chodat and Hassl. confirm previous records. Karyotype formulae revealed the existence of metacentric and submetacentric chromosomes, and the chromosomal asymmetry indexes did not show significant differences between taxa. The chromosome length of xerophilous and endemic M. detinens and M. ostenii differed from the rest of species, indicating that this parameter could have taxonomic value. In addition, the relationship between total chromosome length and climatic parameters showed that diploid species of marginal areas of distribution have a larger chromosome size, and that this could be related with mechanisms of ecological adaptation.
\end{abstract}

Key words: Chromosome, Cytogenetics, Karyotype, Leguminosae, Mimosa, Mimosoideae.

\section{INTRODUCTION}

Taxonomy, distribution and phylogeny of the genus - The genus Mimosa L. comprises ca. 540 species of pantropical and pansubtropical distribution (SIMON et al. 2011). This genus has two centers of diversification: 1) central and southern Mexico, Cuba, Hispaniola and Orinoco basin and Madagascar, and 2) southern South America, which includes Amazonas basin, Brazilian Planalto, Paraguay, Northern Argentina and Uruguay (BARNEBY 1991).

In southern South America, Mimosa is highly diversified in campos and cerrados from the Bra-

\footnotetext{
*Corresponding author: e-mail: mmorales0007@gmail.
}

zilian Planalto. In Argentina, this genus is particularly abundant in northeastern and northwestern extremes, where $85-90 \%$ of the species grow. Some taxa extend or are restricted to the southernmost regions of distribution of the genus, where the temperature is lower and frosts are more frequent (BURKART 1948; FORTUNATO et al. 2008). A similar situation is observed in North America, where only a few species are found in the temperate areas of the United States (BARNEBY 1991).

BENTHAM (1876) realized the first monograph on this genus and recognized two sections: Habbasia DC. and Eumimosa. Later, BARNEBY (1991) revised the neotropical species and proposed five sections: Mimadenia (with diplostemonous flowers and extrafloral nectaries), Batocaulon DC. (=diplostemonous flowers, within extrafloral nectaries), Habbasia DC. (=diplostemonous flowers, extrafloral nectaries absent, indumen- 
tum of calcarate setae), Mimosa (=haplostemonous flowers, corolla lobes glabrous or with single hairs) and Calothamnos Barneby (=haplostemonous flowers, corolla lobes with plumose or stellate hairs or setae). However, recent phylogenetic studies based on chloroplast sequences and optimized morphological characters have revised the proposal of BARNEBY (1991) and suggested that Batocaulon and Calothamnos may not be natural groups (BESSEGA et al. 2008; 2011; SimON et al. 2009; 2011).

Cytological studies - The cytology of this genus is poorly studied. The chromosome number and ploidy levels are known in only 20\% of its species. Most studies have been carried out in Southern South America. The most cited chromosome numbers are $2 \mathrm{n}=2 \mathrm{x}=26$ and $2 n=4 x=52$, but also $2 n=3 x=39,2 n=6 x=78$ and $2 n=8 x=104$ have been found (COLEMAN and DeMenezes 1980; Goldblatt 1981a; Alves and CarvalHo-Custódio 1983; GoldblatT 1984, 1988; GOLDBLATT and JohNSON 1998; SEIJO 1993 , 1999; SEIJO and FERNÁNDEZ 2001; DAHMER et al. 2011).

IsELY (1971) postulated that the basic chromosome number is $x=13$, which was confirmed by other authors (GoldBlatT 1981a; SEIJO 1993 , 1999, 2000; SeIJO and Fernández 2001). However, it is important to point out that, in Mimosoids, $\mathrm{x}=13$ is considered a chromosome number derived by disploidy from $\mathrm{x}=14$ (Poggio et al. 2008).

In Mimosa, polyploidy is a frequent phenomenon, because ca. $22 \%$ of the species studied have high levels of ploidy, i.e. $4 x, 6 x$ or $8 x$ (GoldBlatT 1981, 1984, 1985, 1988; GoldBLATT and Johnson 1990, 1998; SEIJO 1993, 1999; GoldblatT and Johnson 2000; Seijo 2000; Seijo and Fernández 2001; GoldblatT and JoHnSON 2003, 2006; Morales et al. 2007; DaHMER et al. 2011). In some groups of this genus, polyploidy would be an important mode of speciation, as discussed in M. debilis Humb. and Bonpl. ex Willd. complex (Morales et al. 2010). In the southernmost species, polyploidy appears to be a mechanism to colonize new habitats (SEIJO and FERNÁNDEZ 2001). However, entire role of polyploidy in the evolution and geographic distribution of Mimosa requires a study of more chromosome counts from a wide range of species and accessions, especially from higher latitudes (DAHMER et al. 2011).

Like in other Mimosoids, chromosomes of Mimosa are very small, and it is difficult to obtain cells adequate for karyological studies (STEB-
BINS 1971; SEIJO 1993; SHUKOR et al. 1994). This is one of the reasons that explain the absence of karyotype studies in this genus. Thus, the aim of this work was to study karyotypical parameters in different species of Mimosa from Southern South America that were included in the sections Batoucalon and Mimosa. We discussed the data obtained based on the systematic position and geographic distribution of the taxa.

\section{MATERIAL AND METHODS}

Plant material - We collected vouchers in Argentina and Paraguay during field trips carried out from 2005 until 2008. We deposited the specimens at the Instituto de Recursos Biológicos, CIRN-INTA, Buenos Aires, Argentina (BAB) and Facultad de Ciencias Químicas, Universidad de Asunción, Paraguay (FCQ), with duplicates in Instituto de Botánica Darwinion (SI) and Instituto de Botánica del Nordeste (CTES) (Table 1).

We determined the specimens according to the proposals of BARNEBY (1991), and recent contributions of FORTUNATO et al. (2008) and Morales and Fortunato (2010). The geographic distribution of the taxa was inferred from taxonomic bibliography (BARNEBY 1991), observations during field trips, and records of herbarium specimens from the following institutions: BA, BAA, BAF, BAB, CGMS, CORD, CPAP, CTES, FCQ, G, ICN, LIL, LPB, MBM, MO, NY, RB, SI, SP, SPF (see Appendix). We mentioned Ecoregions following OLSON et al. (2001). Instituto de Clima y Agua, CIRN-INTA (Hurlingham, Argentina), provided us with climatic data from the localities or closest locality where the specimens were collected.

Chromosome studies - Seeds were simultaneously collected with plant material during the field trips. For the mitotic studies, were used root meristems obtained from seeds germinated on Petri dishes at room temperature. Root tips $(1-2 \mathrm{~cm})$ were pretreated with 8 -hydroxyquinoline $0.002 \mathrm{M}$ at room temperature for $4-5 \mathrm{~h}$ and then fixed in absolute ethanol-glacial acetic acid (3:1). The material fixed and conserved in $70 \%$ ethanol was washed in buffer solution of 0.01 $\mathrm{M}$ citric acid-sodium citrate $\mathrm{pH} 4.6$ and then transferred to an enzymatic solution containing $2 \mathrm{ml}$ cellulase 2\% (Ozonuka R-10) and 20\% liquid pectinase for $120-150$ ' at $37^{\circ} \mathrm{C}$, and washed again with buffer solution.

The root tips obtained were macerated in 
a drop of dye (acetic hematoxylin), and the "squash" technique was applied. In each sample, we counted 10-20 metaphases and conserved the slides with Euparal as a mounting medium.

Karyotypical studies - To analyze karyotype formulae, karyotypical parameters (total chromosome length (TCL) and asymmetry indexes), and the corresponding idiograms, we selected the best mitotic metaphases that showed similar chromosome condensation (5-10 cells per individual, and 2-4 individuals in each taxon). We used the chromosome nomenclature according to LEVAN et al. (1964): "m" for metacentric and "sm" for submetacentric chromosomes. TCL was measured with Micromeasure Program (REEVES 2004). Intra- and interchromosomal asymmetry indexes, $A_{1}$ and $A_{2}$, were calculated, according to ROMERO ZARCO (1986). To calculate these indexes, we used the following formulae:

$$
A 1=1-\frac{\sum_{i=1}^{n} \frac{q i}{p i}}{n}
$$

where $q_{i}$ represents the mean length of the short arm, $p_{i}$ the mean length of the long arm in each pair of homologous chromosomes, and $n$ the number of pairs or groups of homeologous chromosomes, and

$$
\mathrm{A}_{2}=\mathrm{SX}^{-1}
$$

where $S$ represents standard deviation and $X$ the mean of chromosome length.

We tested the differences in karyotypical parameters with KRUSKAL-WALLIS's method (1952) and carried out comparisons of pairs among mean values of ranges. Mean values and standard deviation were calculated for each param- eter. The statistical analysis was carried out with Infostat program (Di RiENzo et al. 2009).

\section{RESULTS}

Chromosome numbers - All the taxa studied were diploid, with $2 \mathrm{n}=2 \mathrm{x}=26$ (Table 1; Fig. 1 A-G). Chromosome numbers of $M$. detinens Benth., M. ostenii Speg. ex Burkart and M. xanthocentra var. mansii were first records, while those of M. bexandra M. Micheli, M. debilis var. debilis, M. uliginosa Chodat and Hassl. and $M$. urugüensis Hook. and Arn. confirmed previous reports.

Karyotype formula - The study of chromosome morphology showed that $M$. detinens, $M$. ostenii, M. uliginosa had ca. 7-8 metacentric chromosomes, being the rest submetacentric or metacentric-submetacentric. Instead, $M$. hexandra, M. urugüensis, $M$. debilis var. debilis and $M$. xanthocentra var. mansii presented 10-11 metacentric and 1-2 submetacentric or metacentricsubmetacentric chromosomes (Table 2; Fig. 2 A-G).

Karyotype parameters - Regarding the $\mathrm{A}_{1}$ index, variations detected in the karyotype formula showed differences between species of Ser. Farinosae, which had a higher number of submetacentric chromosomes, and $M$. hexandra, $M$. xanthocentra, M. urugüensis and $M$. debilis var. debilis, which had a higher proportion of metacentric chromosomes. The $A_{2}$ asymmetry index revealed that the chromosome size did not vary notably within each taxon but varied significantly between the studied taxa.

TCL showed significant differences only at $p=0.05$, and we observed that the species of $M$.

TABLE 1 - Vouchers, localities and chromosome numbers of Mimosa species from Southern South America.

\begin{tabular}{lllc}
\hline \multicolumn{1}{c}{ Taxon } & \multicolumn{1}{c}{ Voucher } & \multicolumn{1}{c}{ Locality } & Previous records \\
\hline M. detinens Benth. & R. H. Fortunato et al. 9453 (BAB) & ARG. Córdoba. & $*$ \\
M. ostenii Burkart & M. Morales et al. 617 (BAB) & ARG. Entre Ríos. & $*$ \\
M. uliginosa Chod. \& Hassl. & R. H. Fortunato et al. 9010 (BAB) & ARG. Corrientes. & Seijo, 1993 \\
M. urugüensis Hook. \& Arn. & Prüner s.n. (BAB 92350) & ARG. Entre Ríos. & Seijo, 1993 \\
M. hexandra M. Micheli & F. Mereles \& R. Degen 6023 (MO 5303427) & PAR. Presidente Hayes. & $*$ \\
& R. H. Fortunato et al. 9176 (BAB) & PAR. Central. & $*$ \\
M. debilis Humb. \& Bonpl. ex Willd. var. debilis & R. H. Fortunato et al. 7298 (BAB) & ARG. Salta. & Seijo, 2000 \\
M. xanthocentra Mart. var. mansii (Benth.) Barneby & R. H. Fortunato et al. 9180 (BAB) & PAR. Central. & $*$ \\
& R. H. Fortunato et al. 9200 (BAB) & PAR. San. Pedro. & $*$
\end{tabular}

* indicates first chromosome countings. All species showed the chromosome number $2 \mathrm{x}=26$. 


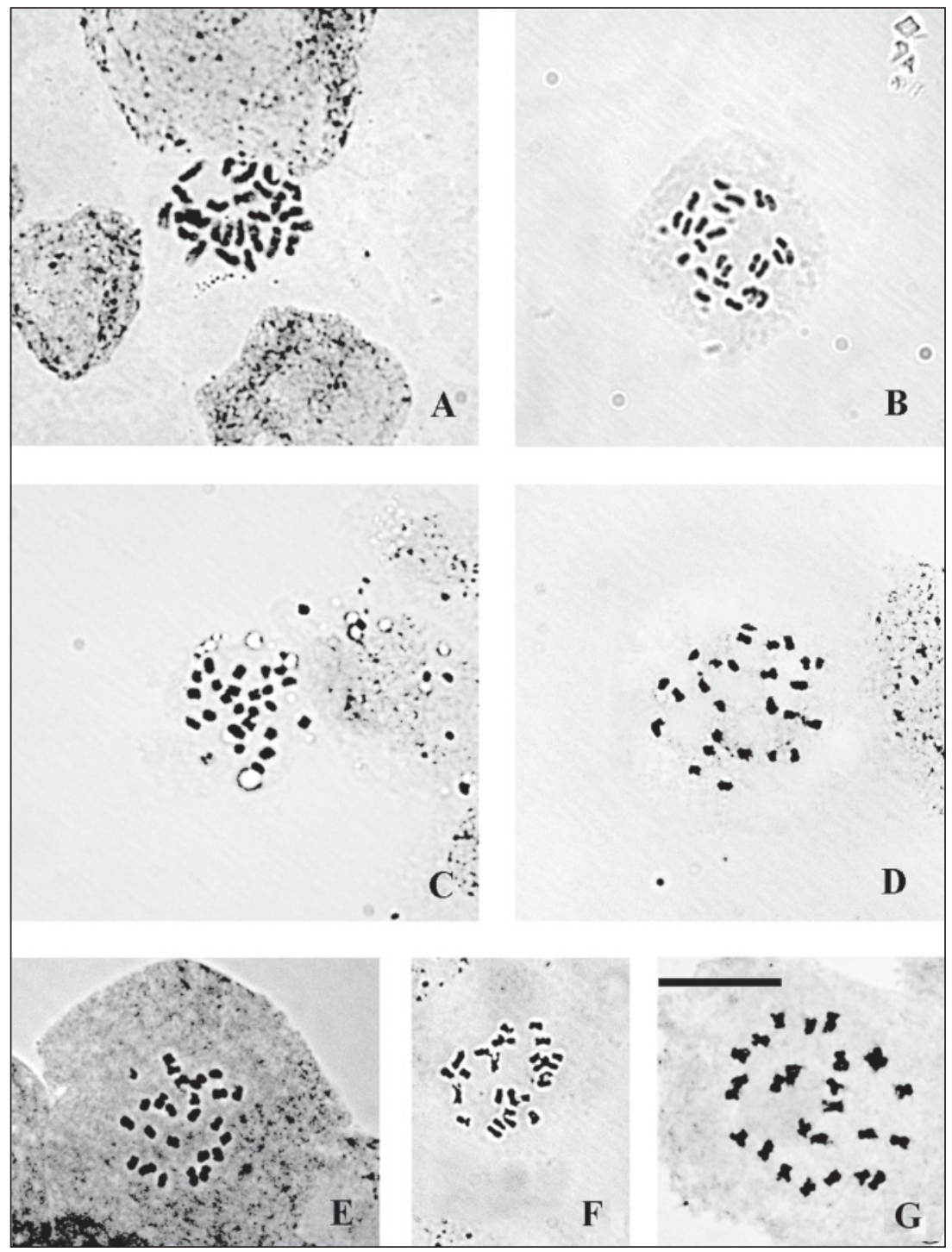

Fig. 1 - Mitotic metaphases of Mimosa from Southern South America. All species had $2 \mathrm{n}=2 \mathrm{x}=26$. A. M. detinens. B. M. ostenii. C. M. hexandra. D. M. debilis var. debilis. E. M. urugüensis. F. M. xanthocentra var. mansii. G. M. uliginosa. Scale Bar $=10 \mu \mathrm{m}$.

Sect. Batocaulon Ser. Farinosae analyzed (M. detinens and M. ostenii) had larger chromosomes and differed significantly from $M$. xanthocentra, $M$. hexandra, and M. debilis var. debilis (Table 2).

\section{DISCUSSION}

Chromosome numbers of $M$. detinens, $M$. ostenii and M. xanthocentra var. mansii are first records, while those of $M$. hexandra, $M$. debilis var. debilis, M. urugüensis and M. uliginosa confirm previous records (SEIJO 1993; SEIJO 1999;
Morales et al. 2010; DAHMER et al. 2011). The studies confirm $\mathrm{x}=13$ as the basic chromosome number of the genus (ISELY 1971; GOLDBLATT 1981b). It is remarkable that various morphological groups with different cytotypes $(2 \mathrm{x}$ and $4 \mathrm{x}$ ) have been previously recorded in $M$. debilis var. debilis (MORALEs et al. 2010). The individuals studied in this work belong in morphology and geographic distribution to $M$. debilis var. debilis sensu stricto, and, in concordance with previous studies, had $2 \mathrm{n}=2 \mathrm{x}=26$.

The visualization of chromosome constrictions constitutes a problem to carry out karyo- 


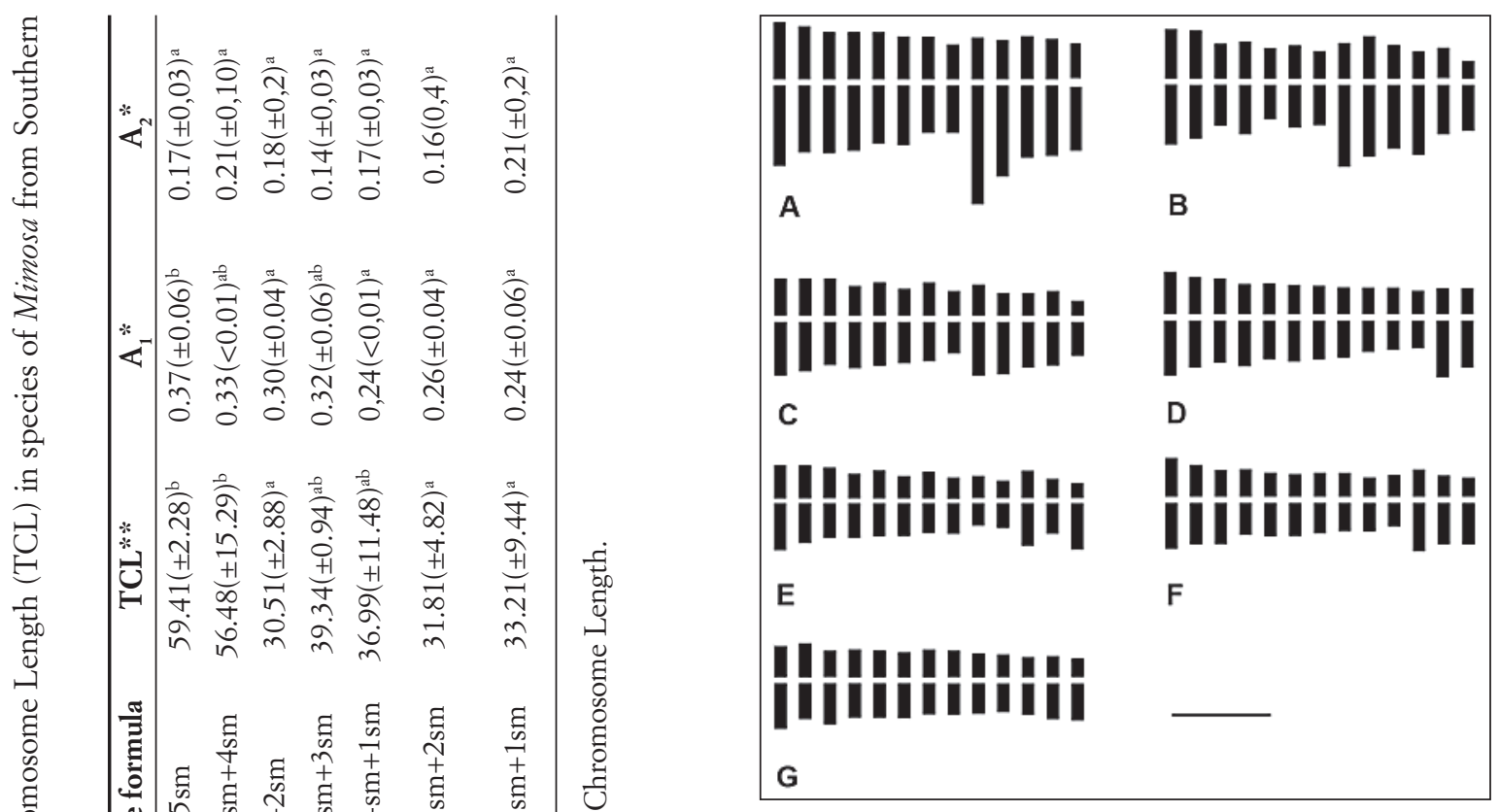

Fig. 2 - Idiograms of Mimosa species from Southern South America. A. M. detinens. B. M. ostenii. C. M. uliginosa. D. M. urugüensis. E. M. hexandra. F. M. xanthocentra var. mansii. G. M. debilis var. debilis. Scale Bar $=2 \mu \mathrm{m}$.

type studies in Mimosoids (José G. SEIJO, pers. comm.; SHUKOR et al. 1994; Morales et al. 2010), but the technique used in the present work allowed us to observe the chromosome morphology in most of the species. Our results indicate that the karyotype of the species of Mimosa studied is relatively symmetric, with metacentric and submetacentric chromosomes. This is reflected in the low asymmetric index $A_{1}$ of all the species. Thus, the studied species of Mimosa have a karyotype similar to that of other Mimosoids, such as Pithecellobium Mart., Acacia Mill. and Prosopis L., where other authors also found a high proportion of metacentric and submetacentric chromosome pairs (GÓMEZ ACEVEDO and TAPIA PASTRANA 2003; 2005).

The $A_{2}$ asymmetry index was relatively low and did not show differences among taxa.

Our studies about chromosome size showed that the chromosomes of Mimosa are small, generally smaller than $2 \mu \mathrm{m}$, in agreement with that found in other genera of Mimosoids (SEIJO 1993; SuKOr et al. 1994; SEIJO 1999, 2000; SEIJO and FERNÁNDEZ 2001). We found significant differences among the taxa studied. The species of Ser. Farinosae (M. detinens and M. ostenii) had larger chromosome size. Although the number of species studied is low, it is interesting to observe 


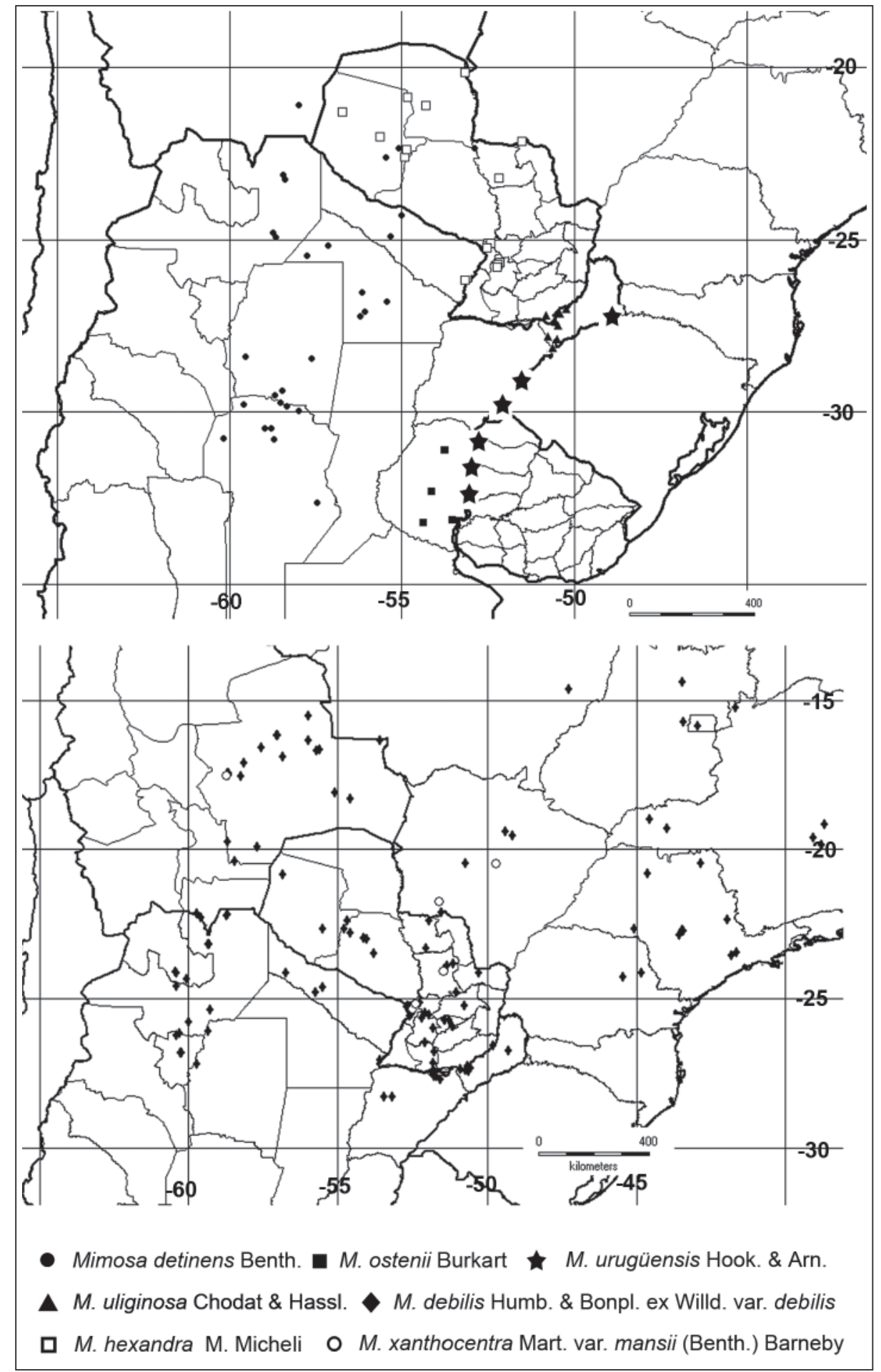

Fig. 3 - Geographic distribution of Mimosa species studied. A) Sect. Batocaulon. B) Sect. Mimosa.

that the species with larger chromosome length also showed a karyotype with lowest metacentric: submetacentric chromosomes relation, which is observed in the high intrachromosomal asymmetry. Only M. urugüensis combined high length chromosome with relatively symmetric karyotype (Table 2, Fig. 2). This trend was found in other groups of Legumes, such as Phaseolus 
TABLE 3 - Geographic distribution of Mimosa species from Southern South America.

\begin{tabular}{|c|c|c|c|}
\hline Taxon & $\begin{array}{l}\text { Ploidy } \\
\text { levels }\end{array}$ & $\begin{array}{l}\text { Geographic distribution } \\
\text { and latitudinal range }\end{array}$ & Ecoregion \\
\hline M. detinens Griseb. & $2 \mathrm{x}$ & $\begin{array}{l}\text { Bolivia, Paraguay and Argentina } \\
\left(21-31^{\circ} \mathrm{S}\right)\end{array}$ & Dry Chaco \\
\hline M. ostenii Burkart & $2 \mathrm{x}$ & Argentina and Uruguay $\left(30-33^{\circ} \mathrm{S}\right)$ & Espinal \\
\hline M. bexandra M. Micheli & $2 \mathrm{x}$ & $\begin{array}{l}\text { Brazil, Paraguay and Argentina } \\
\left(19-28^{\circ} \mathrm{S} \text {, en el S de Sudamérica) }\right.\end{array}$ & Dry and Humid Chaco \\
\hline M. uliginosa Chodat \& Hassl. & $2 \mathrm{x}$ & $\begin{array}{l}\text { Brazil, Paraguay and Argentina } \\
\left(22-29^{\circ} \mathrm{S}\right)\end{array}$ & $\begin{array}{l}\text { Alto Paraná Atlantic Forests, Mesopotamic } \\
\text { Savannas, Uruguayan Savanna }\end{array}$ \\
\hline M. urugüensis Hook. \& Arn. & $2 \mathrm{x}$ & Argentina and Uruguay $\left(27-33^{\circ} \mathrm{S}\right)$ & $\begin{array}{l}\text { Alto Paraná Atlantic Forests, Mesopotamic } \\
\text { Savannas, Uruguayan Savanna, Espinal. }\end{array}$ \\
\hline $\begin{array}{l}\text { M. debilis Humb. \& Bonpl. ex } \\
\text { Willd. var. debilis }\end{array}$ & $2 \mathrm{x}$ & $\begin{array}{l}\text { Brazilian Planaltine to Northern } \\
\text { Argentina }\left(8-27^{\circ} S\right) \text {. }\end{array}$ & $\begin{array}{l}\text { Madeira-Tapajós moist Forests, Pantanal, } \\
\text { Cerrado, Dry and Humid Chaco. }\end{array}$ \\
\hline $\begin{array}{l}\text { M. xanthocentra Mart. var. mansii } \\
\text { (Benth.) Barneby }\end{array}$ & $2 \mathrm{x}$ & $\begin{array}{l}\text { Brazil, Bolivia, Paraguay and } \\
\text { Northern Argentina }\left(14-27^{\circ} \mathrm{S}\right) .\end{array}$ & $\begin{array}{l}\text { Southern Yungas, Dry Chaco, Humid } \\
\text { Chaco, Cerrado, Chiquitano Dry Forests. }\end{array}$ \\
\hline
\end{tabular}

(Mercado-Ruaro and Delgado-Salinas 2009), in which species with high TCL had more symmetric karyotype.

It is interesting to point out that a high correlation between parameters of chromosome size, such as TCL and total chromosome area, and nuclear DNA content has been found in previous works (OuZu et al. 1997; MOHANTY et al. 2004). For this reason, it is possible to suppose that significant differences in chromosome size could reflect variations in genome size.

The data presented here suggest that TCL could be useful to distinguish taxa, for example Mimosa Sect. Batocaulon Ser. Farinosae. It is important to point out that this Series comprises only four species that are xerophilous trees endemic of Chaco and adjacent areas, whose morphological characters seem to be generally stable in the populations. Contrarily, the rest of the Series and Subseries studied are subshrubs or shrubs with a wide subtropical distribution, which exhibit high morphological diversification. In this way, it is important to observe that Ser. Farinosae could be distinguished from other groups of this genus by some chromosome parameters. Furthermore, decisive conclusions about the relation between karyotypical parameters and taxonomy in Mimosa must be supported by studying a larger number of populations in each taxon.

Regarding the geographic distribution, according to our observations and those of others (BURKART 1948; BARNEBY 1991; IZAGUIRRE and BeyHaut 2003), some species, such as $M$. debilis var. debilis, M. hexandra and $M$. xanthocentra var. mansii, reach only $27^{\circ}-29^{\circ} \mathrm{S}$ in their south- ernmost distribution. The other species studied reach higher latitudes, growing in warm temperate areas. Mimosa detinens has subtropical distribution but extends to southernmost areas of Dry Chaco $\left(31^{\circ} \mathrm{S}\right), M$. urugüensis grows only in warm temperate areas from the coast of Río Uruguay, and M. ostenii appears to be restricted to the Espinal Ecoregion, reaching $33^{\circ} \mathrm{S}$ (Table 3; Figs. 3, 4).

It is possible to observe that the studied species with strictly subtropical distribution that can not extent further than $30^{\circ} \mathrm{S}$ present low values of TCL and a more symmetric karyotypes. In contrast, $M$. detinens, $M$. ostenii, $M$. urugüensis and $M$. uliginosa, which grow in warm temperate environments, have high values of TCL and a more asymmetric karyotypes.

Mimosa is a genus especially diversified in cerrado from the Brazilian Planalto and adjacent areas (BURKART 1948; BARNEBY 1991; SIMON and Proença 2000; Seijo and Fernández 2001). So, the marginal areas of distribution in southern South America could be the highest latitudes of its distribution area, with colder climate (Table 4), such as the Dry Chaco, Pampas and Espinal ecoregions. Relatively few species of Mimosa grow in these regions (BURKART 1948; FORTUNATO et al. 2008), possibly because most of the species of this genus cannot adapt to extreme climatic conditions.

We related the variation in TCL to some climatic data of voucher localities, such as annual mean temperature, annual total rainfall and annual frost frequency, and found that the species collected in areas with highest number of annual days with frosts had highest TCL values (Fig. 


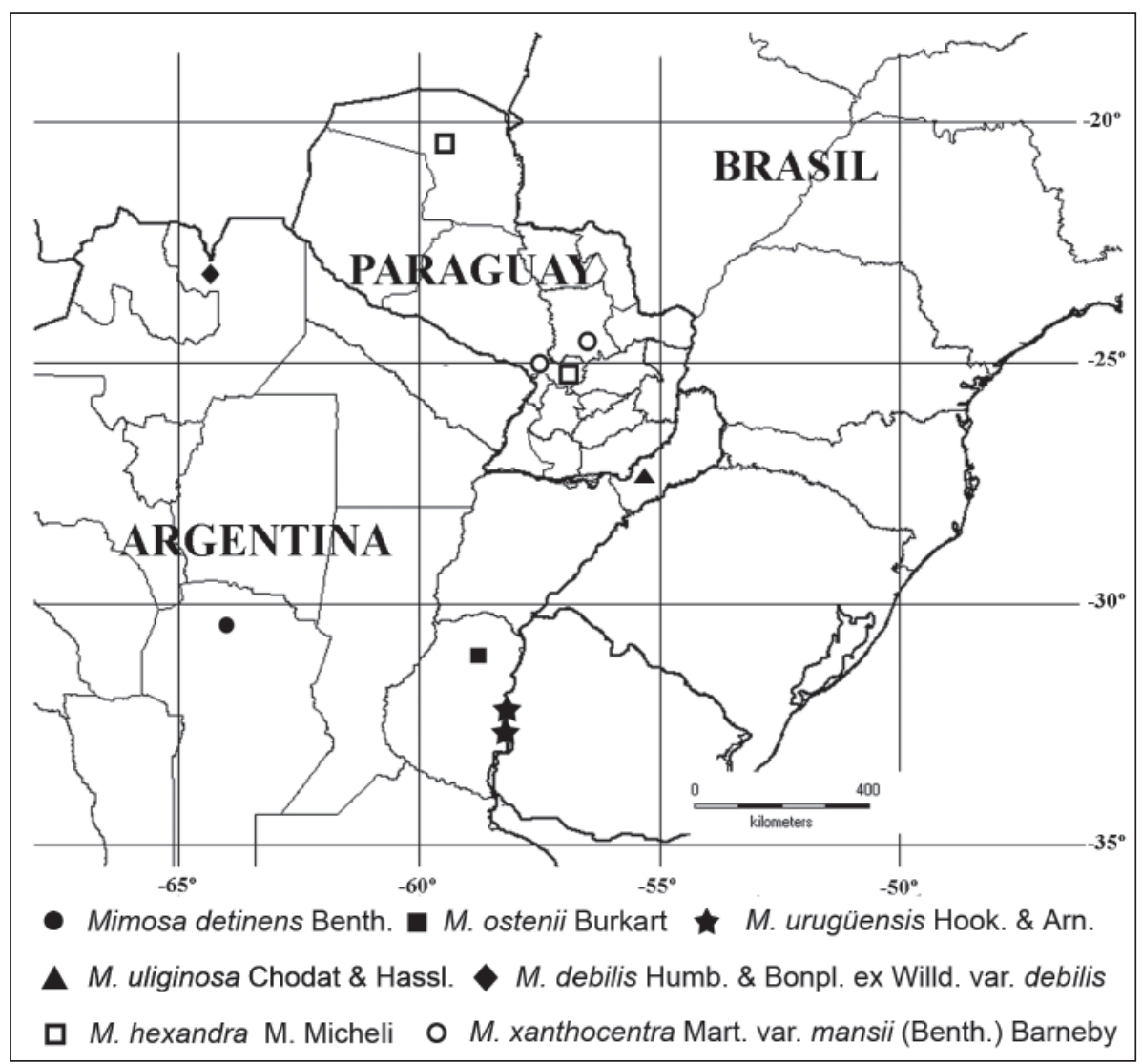

Fig. 4 - Voucher's localities from specimens of the studied Mimosa species.

5A). In addition, TCL decreased with annual mean temperature (Fig. 5B). In this way, our data appear to be in agreement with that obtained by other authors, who found that species comparatively more tolerant to frosts and low tempera- tures had an increased genome size (WAKAMIYA et al. 1993; MACGILlivraY and GRIME 1995; SUdA et al. 2003; KNIGHT et al. 2005).

This relation between environment and karyotype parameters could indicates that varia-

TABLE 4 - Climatic data from collection localities of plant material studied ${ }^{1}$.

\begin{tabular}{lcccc}
\hline \multicolumn{1}{c}{ Locality } & $\begin{array}{c}\text { Annual rainfall } \\
(\mathbf{m m})\end{array}$ & $\begin{array}{c}\text { Annual frost fre-- } \\
\text { quency (days) }\end{array}$ & $\begin{array}{c}\text { Annual average } \\
\left.\text { temperature }{ }^{\circ} \mathbf{C}\right)\end{array}$ & $\begin{array}{c}\text { Potencial } \\
\text { evapotranspiration } \\
(\mathbf{m m})\end{array}$ \\
\hline Gualeguaychú & 1105,2 & 10 & 18 & 1087,2 \\
Concordia, Entre Ríos, Argentina & 1330,4 & 8,6 & 18,8 & 1073,8 \\
Mercedes, Corrientes, Argentina & 1463,3 & 6,2 & 19,9 & 1188,1 \\
Tandil, Buenos Aires, Argentina & 901,3 & 13,9 & 13,9 & 988,9 \\
Posadas, Misiones, Argentina & 1787,1 & 0,5 & 22,1 & 1261,1 \\
Corrientes Aero, Corrientes, Argentina & 1424,2 & 1 & 21,6 & $\mathrm{ND}$ \\
Formosa, Formosa, Argentina & 1417,8 & 0,7 & 22,7 & 1438,8 \\
Villa María, Córdoba, Argentina & 827,7 & 24,1 & 18,3 & $\mathrm{ND}$ \\
Orán, Salta, Argentina & 995,8 & 1,5 & 22,1 & 1102,8 \\
Paso de los Libres, Corrientes, Argentina & 1560 & 2 & 20,1 & 1207,7 \\
\hline
\end{tabular}

${ }^{1}$ Data provided by Instituto de Recursos Biológicos, CIRN-INTA (Hurligham, Argentina). ND: No data. 
tion in chromosome size, and eventually in genome size, could have an adaptive value, allowing certain species of Mimosa to grow or even colonize adverse environments, in our case, the marginal, coldest and driest areas from Southern South America. Gómez Acevedo and TAPIA PASTRANA (2003) found certain relation between chromosome length and environmental adaptation in Acacia and Prosopis, and it is possible that this pattern also appears in other Mimosoids genera, such as Mimosa.

It is important to point out that other mechanisms, such as polyploidy, could be operating to colonize adverse environments or adapt to specific ecological niches, especially in higher latitudes (STEBBins 1971; SOLTis et al. 2003). SEIJO and FERnÁndeZ (2001) found cytological evidence supporting this hypothesis in the genus Mimosa; they observed that polyploid frequency and ploidy levels increase with latitude, but it was only analyzed in a few species from Southernmost South America and it cannot still be extrapolate to all taxa of megadiverse genus Mimosa. In the present work we only studied some diploid taxa of Mimosa, whose mechanism of adaptation or dispersion could be a variation in genome size.

Conclusions - We report the karyotype of $M$. detinens, M. ostenii, M. hexandra, M. debilis, $M$. xanthocentra, M. uliginosa and $M$. uragüensis for the first time; these species have a relatively symmetric karyotype and small size of chromosomes, like that observed in other Mimosoids. These results indicate that there are inter-specif-

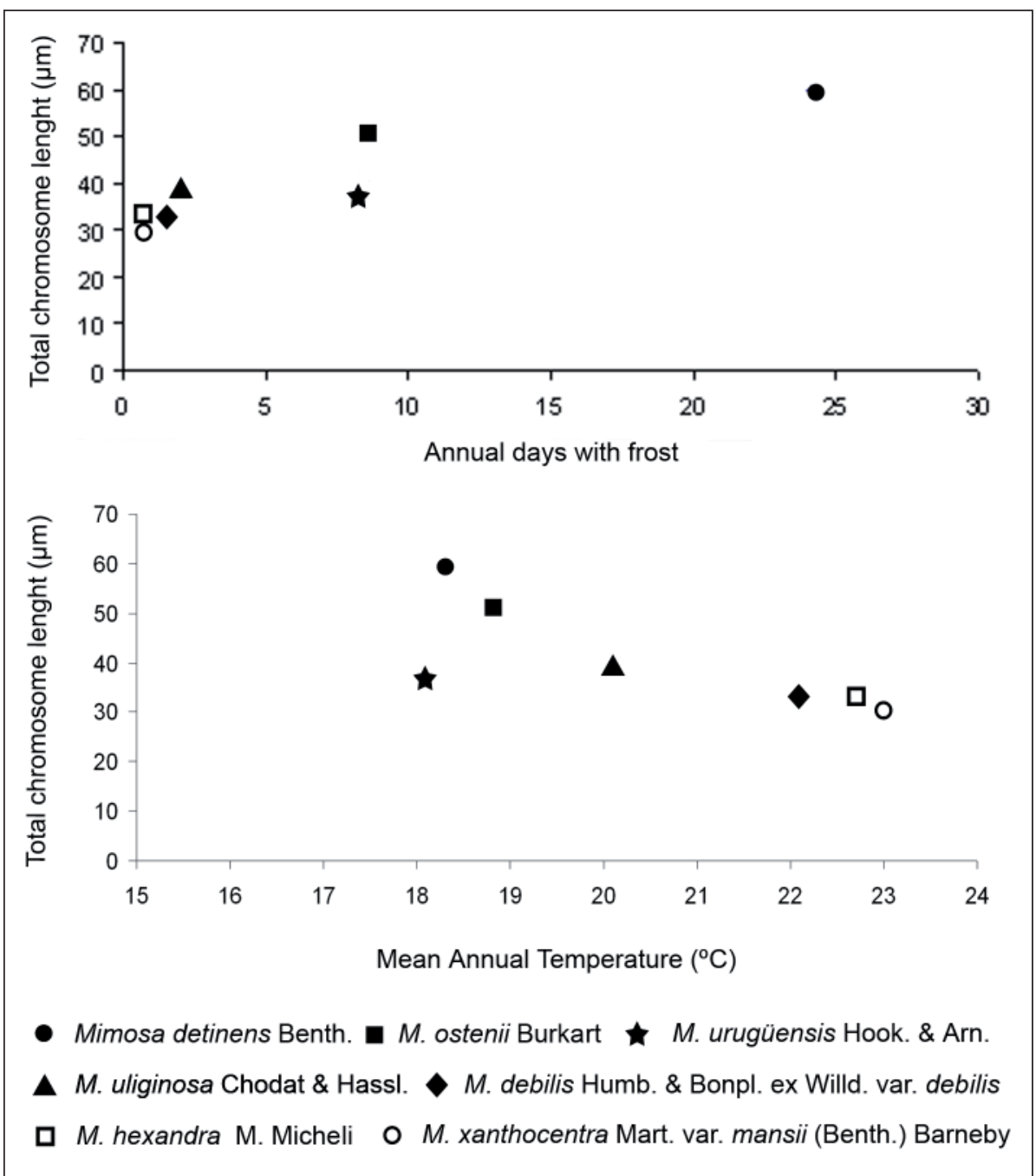

Fig. 5 - Number of annual days with frosts (Fig. 5.A.) and Mean annual temperature (Fig. 5.B.) and its relation with Total Chromosome Length of studied species of Mimosa from Southern South America. Climatic data were registered from collection localities or adjacent areas. 
ic differences in the formula and asymmetry of the karyotype and chromosome size, although a larger number of specimens and populations from Southern South America are necessary to deduce the evolutionary changes in the karyotype. In addition, we found significant differences among species in chromosome length, which could be related to their ability to adapt or colonize adverse environments, especially at highest latitudes, with colder climatic conditions. We may also conclude that variations in chromosome size are related with geographic dispersion or ecological adaptation in some diploid species of the genus Mimosa. However, to infer this hypothesis to other groups of the genus, it is necessary more karyological data, especially for the species that grow in other geographic regions.

Aknowledgements - We thank Fátima Mereles, Lidia Pérez de Molas, Rosa Degen and Cristian Vogt in Paraguay, and Guillermo Seijo, Roberto Neumann, P. Prüner, Esteban Meza Torres and Juan Manuel Rodríguez in Argentina, for their help during field works. We appreciate the collaboration of professionals from Instituto de Clima y Agua, CIRN-INTA (Hurlingham, Argentina): Teresa Bocca, for statistical assessing and Graciela Galvani, for providing climatic data. We recognize the technical assessing of Diego Fink to image treatment and we are grated for the collaboration of herbaria cited in Material and Methods. We want also to thank "Consejo Nacional de Investigaciones Científicas y Técnicas (CONICET)" for the postgraduate fellowship given to Matías Morales. This research was supported by grants PIP 5560 (CONICET) given to Renée H. Fortunato, PIP 5927 (CONICET) to Lidia Poggio, PID 2006-2008 B06001-06 (Universidad de Morón) given to Matías Morales, X178 (Universidad de Buenos Aires) to Lidia Poggio, and Myndel Botanica Foundation Collection trip Grants 2004, 2005 and 2007 given to Renée H. Fortunato and collaborators.

\section{REFERENCES}

Alves M.A.O. and De Carvalho Custódio A.V., 1983 - Citogenética de leguminosas coletadas no estado de Ceará. Braz. J. Genet., 12: 81-92.

Barneby R., 1991 - Sensitivae Censitae: A description of the genus Mimosa Linnaeus (Mimosaceae) in the New World. Mem. New York Bot. Gard., 65: 1-835.

Bentham G., 1876 - Mimosa. In A.W. Eichler, C.F.P. Martius and I. Urban (Eds.), "Flora Brasiliensis", n. 15(2), p. 294-390. München, Germany.

Bessega C., Hopp H.E., Fortunato R.H., 2008 Toward a phylogeny of Mimosa (Leguminosae, Mimosoideae): a preliminary analysis of southern South American species based on chloroplast DNA sequence. Ann. Mo. Bot. Gard., 95(4): 567-569.

Bessega C. and Fortunato R.H., 2011 - Section Mimadenia: its phylogenetic relationships within the genus Mimosa (Leguminosae, Mimosoideae) using plastid trnL-F sequence data. Austr. Syst. Bot., 24(2): 104-110.

BurKarT A., 1948 - Las especies de Mimosa de la Flora Argentina. Darwiniana, 8(1): 9-231.

Coleman J.R. and DeMenezes E., 1980 - Chromosome numbers in Leguminosae from the State of São Paulo, Brazil. Rhodora, 82: 475-481.

DAHMER N., SimOn, M.F., SChifino-WitTMAnN M.T., Hughes C.E., Miotto S.T.S., Giuliani J.C., 2011 - Chromosome numbers in the genus Mimosa L.: cytotaxonomic and evolutionary implications. Plant Syst. Evol., 291 (3-4): 211-220.

Di Rienzo J.A., Casanoves F., Balzarini M.G., GonZÁlez L., TABLADA M. and RoBlEDO C.W., 2009 - InfoStat versión 2009. Grupo InfoStat, FCA, Universidad Nacional de Córdoba, Argentina.

Fortunato R.H.; Beyhaut R.; Costa Bortoluzzi R.L.; Gómez Sosa E.V.; IzaguirRe P.; Lima H.C.; MiotTo S.T.S.; Moura Baptista L.R.; UlibarRI E.A., 2008 - Fabaceae. In F. Zuloaga, O. Morrone and M.J. Belgrano (Eds.), "Catálogo de Plantas Vasculares del Cono Sur", vol. 2, p. 2078-2251.

Goldblatt P., 1988 - Index to Plant Chromosome Numbers 1984-1985. Monographs in Systematic Botany from the Missouri Botanical Garden, 23: 1-264. Missouri Botanical Garden Press.

GoldblatT P., 1985 - Index to Plant Chromosome Numbers 1982-1983. Monographs in Systematic Botany from the Missouri Botanical Garden, 13: 1-224. Missouri Botanical Garden Press.

Goldblatt P., 1984 — Index to Plant Chromosome Numbers 1979-1981. Monographs in Systematic Botany from the Missouri Botanical Garden, 8: 1-427. Missouri Botanical Garden Press.

Goldblatt P., 1981 (a) - Index to Plant Chromosome Numbers 1975-1978. Monographs in Systematic Botany from the Missouri Botanical Garden, 5: 1-553. Missouri Botanical Garden Press.

GoldBlatT P., 1981 (b) - Cytology and the phylogeny of Leguminosae. In R. Polhill and P. H. Raven (Eds.), "Advances of Legume Systematics", n. 2, p. 427-464. Royal Botanic Gardens, Kew: London.

Goldblatt P. and Johnson D.E., 2006 - Index to Plant Chromosome Numbers 2001- 2003. Monographs in Systematic Botany from the Missouri Botanical Garden, 106: 1-242. Missouri Botanical Garden Press.

Goldblatt P. and Johnson D.E., 2003 - Index to Plant Chromosome Numbers 1998- 2000. Monographs in Systematic Botany from the Missouri Botanical Garden, 94: 1-297. Missouri Botanical Garden Press.

GoldblatT P. and Johnson D.E., 2000 - Index to Plant Chromosome Numbers 1996-1997. Monographs in Systematic Botany from the Missouri Botanical Garden, 81: 1-188. Missouri Botanical Garden Press. 
Goldblatt P. and Johnson D.E., 1998 - Index to Plant Chromosome Numbers 1994-1995. Monographs in Systematic Botany from the Missouri Botanical Garden, 69: 1-208. Missouri Botanical Garden Press.

Goldblatt P. and Johnson D.E., 1990 - Index to Plant Chromosome Numbers 1986-1987. Monographs in Systematic Botany from the Missouri Botanical Garden, 30: 1-243. Missouri Botanical Garden Press.

Gómez-Acevedo S.L. and Tapia Pastrana F., 2003 - Estudio genecológico en Prosopis laevigata, Acacia farnesiana $y$ Acacia schaffneri (Leguminosae). Darwiniana, 41: 47-54.

Gómez-Acevedo S.L. and Tapia Pastrana F., 2005 - El cariotipo de Pithecellobium dulce (Mimosoideae-Leguminosae). Darwiniana, 43: 1-4.

IsELY D., 1971 - Legumes of the United States. IV. Mimosa. Amer. Midl. Naturalist, 85(2): 410-424.

IzaguirRe P. and Beyhaut R., 2003 - Las leguminosas en Uruguay y regiones vecinas, parte 2: Caesalpinioideae, y parte 3: Mimosoideae. Ed. Hemisferio Sur, Montevideo.

Knight C.A., Molinari N.A. and Petrov D.A., 2005 - The Large Genome Constraint Hypothesis: Evolution, Ecology and Phenotype. Ann. Bot., 95: 177 190.

KRUSKAL W.H. and.WALlis W.A., 1952 - Use of ranks in one criterion variance analysis. Journal of the American Statistical Association, 47: 586-621.

Levan A., Fredga K. and Sandberg A.A., 1964 Nomenclature for centromeric position on chromosomes. Hereditas, 52: 201-219.

MacGillivray C.W. and Grime J.P., 1995 - Genome size predicts frost resistance in British herbaceous plants: implications for rates of vegetation response to global warming. Functional Ecology, 9: 320 325 .

Mercado-Ruaro P. and Delgado-Salinas A., 2009 - Karyotypic analysis in six species of Phaseolus L. (Fabaceae). Caryologia, 62(3): 167-170.

Mohanty I.C., Mahapatra D., Mohanty S. and Das A.B., 2004 - Karyotype analyses and studies on the nuclear DNA content in 30 genotypes of potato Solanum tuberosum L. Cell Biol. Int., 28(1-2): 625-633.

Morales M. and Fortunato R.H., 2010 - Novedades taxonómicas y nomenclaturales en Mimosa serie Mimosa subserie Mimosa (Leguminosae, Mimosoideae) para Sudamérica Austral. Candollea, 65: 169-184.

Morales M., WulfF A.F., Fortunato R.H. and Poggio L., 2007 - Estudio cromosómico en especies de Mimosa (Mimosoideae, Fabaceae) del S de Sudamérica. Bol. Soc. Argent. Bot., 42 (Supl.): 55-56.

Morales M., Wulff A.F,. Fortunato R.H. and PogGIO L., 2010 - Chromosome and morphological studies in the Mimosa debilis complex (Mimosoideae, Fabaceae) from Southern South America. Austr. J. Bot., 58 (1): 12-22.

Ouzu S., Ikehashi H., Ohmido N., Ohtsubo H.,
Ohtsubo E. and Fukui K., 1997 - Repetitive sequences: cause for variation in genome size and chromosome morphology in the genus Oryza. Plant Molecular Biology, 35: 791-799.

Poggio L., Espert S. and Fortunato R.H., 2008 Citogenética evolutiva en Leguminosas americanas. Rodriguesia, 59(3): 423-433.

Olson D.M., Dinerstein E., Wikramanakaye E.D., Burgess N.D., Powell G.V.N., UnderwoOd E.C., D’Amico J.A., Itoua I., Strand H.E., MorRISON J.C., LOUCKS C.J., AlLnUTT T.F., RiCKETTS T.H., Kura Y., Lamoreux J.F., Wettengel W.W., Hedao P. and Kassem K.R., 2001 - Terrestrial Ecoregions of the World: A New Map of Life on Earth. Bioscience, 51(11): 933-938.

Reeves A., 2001 - MicroMeasure: A new computer program for the collection and analysis of cytogenetic data. Genome, 44: 359-443.

Romero-Zarco C., 1986 - A new method for estimating karyotype asymmetry. Taxon, 35: 526-530.

SeIJo G.J., 1993 - Citogenética en especies argentinas del género Mimosa (Leguminosae). Bol. Soc. Argent. Bot., 29: 219-223.

SEIJO G.J., 1999 - Chromosome studies in Argentinian species of Mimosa. Cytologia, 64: 241-246.

SEIJO G.J., 2000 - Números cromosómicos en especies de Mimosa de Paraguay. Bonplandia, 10: 163-167.

Seijo G.J. and FERnÁndeZ A., 2001 - Chromosome numbers of Some Southernmost Species of Mimosa L. (Leguminosae). Cytologia, 66: 19-34.

Shukor N.A.A., AbD Rashid M. and Itam K., $1994-$ Karyotypic comparison of Acacia mangium Willd., A. auriculiformis $A$. Cunn. ex Benth. and Their F1 bybrids. Silvae Genetica, 43 (2-3): 65-68.

Simon M.F. and ProenÇA C., 2000 - Phytogeographic patterns of Mimosa (Mimosoideae, Leguminosae) in the Cerrado biome of Brazil: an indicator genus of high-altitude centers of endemism?. Biol. Conserv., 96: 279-296.

Simon M.F., Grether R., Queiroz L.P., SÄrkinen T.E., Dutra V.F. and Hughes C.E., 2011 - The evolutionary history of Mimosa (Leguminosae): Toward a phylogeny of the sensitive plants. Amer. Journ. of Bot., 98(7): 1201-1221.

Simon M.F., Grether R., De Queiroz L.P., Skerna C., Pennington T.R., and Hughes C.E., 2009 - Recent assembly of the Cerrado, a neotropical plant diversity botspot, by in situ evolution of adaptations to fire. Proc. Natl. Acad. Sci USA, 106(48): 20359-64.

Soltis E.D., Soltis P.S. and Tate J.A., 2003 - Advances in the study of polyploidy since Plant Speciation. New Phytol., 161: 173-191.

StebBins G.L., 1971 - Chromosomal Evolution in Higher Plants. Edward Arnold Ltd., Bristol.

Suda J., Kyncl T. and Freiova, R., 2003 - Nuclear DNA amounts in Macaronesian angiosperms. Ann. Bot., 92: 152-164.

Wakamiya I., Newton R.J., Johnston, S.J. and Price, J.H., 1993 - Genome size and environmental factors in the genus Pinus. Am. J. Bot., 80: 1235-1241. 


\section{APPENDIX}

Additional selected specimens examined:

M. hexandra M. Micheli - P. Arenas 1390, R.H. Fortunato et al. 873, 9176 (BAB); Ginzbarg et al. 514 (BAB); W. Hahn 2371 (BAB); A. Krapovickas 986 (SI); M. Luckow et al. 4504 (BAB); F. Mereles E R. Degen 6023 (MO 5303427); A. Ragonese E D. Cozzo 1976 (SI); Rojas 7839, 10277 a (SI); T.M. Pedersen 6034 (SI); E.M. Zardini \& P. Aquino 31814 (BAB); E.M. Zardini \& N. Duarte 49880 (BAB); E. M. Zardini E Godoy 50019 (BAB); E.M. Zardini \& L. Guerrero 31882, 31913 (BAB); E.M. Zardini E T. Tilleria 39032, 34882, 34904 (BAB).

M. uliginosa Chod. \& Hassl. - R.H. Fortunato et al. 8059, 9067 (BAB); M. DeMatteis et al. 288 (BAB); U. Eskuche 4895 (BAB); M. Morales et al. 660 (BAB); T. Ibarrola 1069 (BAB); A. Krapovickas et al. 15085 (SI); V. Maruñak 58 (BAB, SI); R. Martínez Crovetto 8672 (BAB); R. Martínez Crovetto E Chiarini 6189 (BAB); A. Schinini \& A. Fernández 6152 (BAB); J.G. Seijo 266, 330, 360 (BAB); Spegazzini s.n. (BAB 17369); Zambini s.n. (BAB 28384).

M. urugüensis Hook. \& Arn. - N. Bacigalupo E R., Guaglianone 1566 (BAB); R.H. Fortunato et al. 9099 (BAB); A. Krapovickas et al. 21072 (SI); A. Lourteig et al. 2745 (SI); M. Múlgura de Romero et al. 3134 (BAB); P. Prüner (BAB 92350), same collector (BAB 92353); R. Martínez Crovetto \& Grondona 4388 (BAB).

M. detinens Benth. - Bartlett 19811, 20105, 20447 (SI); S. Beck \& Liberman 9463 (SI); A. Burkart 20205 (SI); Cordini 35 (SI); Dimitri E Piccinini 53 (BAB 68154); R.H. Fortunato et al. 1525 (BAB, SI); R.H. Fortunato \& M. Luckow 7582 (BAB); Gautier 51 (BAB 65019); W. Hahn 1856 (BAB, $\mathrm{SI}) ; A$. Krapovickas 839 (SI); A. Krapovickas E Cristóbal 46282 (BAB); Larvs E Vogt 5224 (SI); Lazazo 1712, 2188 (SI); M. Luckow et al. 4491 (BAB); Maldonado Brezzone 1546 (SI); V. Maruñak et al. 450 (SI); T. Meyer 2245 (SI); E. Nicora 2759 (SI); Ragonese \& Cozzo 2678 (SI); T. Rojas 2134, 8439 (SI); Sayago 213, 376, 2049, 2246 (SI); G.J. Seijo E A. Krapovickas 1948 (BAB, SI); Soriano 572 (BAB, SI); G. Schulz 10595 (SI); R. Vanni et al. 1946 (SI); E.M. Zardini \& N. Duarte 49916 (BAB).

M. ostenii Burkart - N.M. Bacigalupo E R. Guaglianone 1582 (BAB); R. Guaglianone et al. 174 (BAB); Molfino \& Clos s.n. (BAB 44.264); M. Morales et al. 617 (BAB).

M. xanthocentra var. mansii - R.H. Fortunato et al. 846, 1057, 9180, 9200 (BAB); K.R. Laitart 39 (BAB); A. de Oliveira s.n. (BAB); E.M. Zardini E R. Velázquez 25377 (BAB).
M. debilis Humb. \& Bonpl. ex Willd. var. debilis M.M. Arbo 1733 (CTES 91908), 4877 (BAB); S. Beck 3338 (NY); S. Beck \& R. Seidel 12378 (BAB); Berti \& Escalante 512 (SI); G. Black 5720090 (SI); G. Black \& D. Magalhães 51-13387 (SI); B. Bruderreck 318 (LPB); A.L. Cabrera \& al. 34715 (SI); Cárdenas 4747 (LIL 361516); E.C. Clos 6036 (BAB 51823); D. C. Daly E al. 2133 (LPB); R. de Michel 211 (NY); R. H. Fortunato \& al. 817, 818, $824,1055,1150,1156,1158,3402,4099,7000$, $7955,8534,8620,8603,8741,8790,8808,8826$, 8851, 8886, 8899, 9254, 9264, 9307, 9354 (BAB); Fuentes \& G. Navarro 2642 (CTES); G. Gehrt 3792 (SI); O. Handro 44675 (SI); G. Hatschbach 2157, 6910, 18863 (SI), 29498 (MO), 58793 (MBM 156870); G. Hatschbach \& Guimaraes 21977 (SI); R. Kiesling E al. 9621 (SI); T. Killeen 884, 2412 (LPB); A. Krapovickas E C.L. Cristóbal 34337, 43172 (CTES), 45514 (BAB); A. Krapovickas \& A. Schinini 31419 (CTES 118087), 32290 (CTES 110754), 36285 (LIL 103298); A. Krapovickas et al. 14293 (BAA), 32872, 33278 (CTES); R.M. Harley \& R. Souza 11031 (MO); Herninger 5475 (SI); M.J.G. Hopkins E al. 64 (BAB); J.H. Hunziker 2960 (SI); H.F. Leitão Filho 907 (SI); M. Luckow \& al. 4480 (BAB); H. Luederwaldt 13112 ex Herv ${ }^{\circ}$ Museu Paulista 2140 (SI); A. Macedo E Alvaro Luiz 1571 (SI); F. Mereles 2859 (BAB), 4120 (MO); T. Meyer 21666 (LIL); M. Molina E al. 1781 (BAB); M. Moraes 541 (NY); M. Morales E J. G. Seijo 235, 238, 246, 261 (BAB); O. Morrone et M. Belgrano 5013 (SI); O. Morrone E al. 2972 (SI); T.M. Pedersen 3271 (BAB, G); L. Pérez É al. 2982 (BAB); J.M. Pires 9078 (SI); S. Pierotti 7253 (LIL 233552); V.J. Pott E A. Pott 4779 (MBM); V.J. Pott et al. 1223 (CTES 201178); A. Prosen s.n. (LIL 372189); R. Rossow E al. 608 (BAB); G.H. Rua 424 (BAA); C. Saravia Toledo 1325 (SI); A. Schinini \& M. DeMatteis 33565 (FCQ); S. Sede E al. 63 (BAB); R. Seidel E S.G. Beck 192, 391 (BAB); J.G. Seijo 268, 452, 920 (BAB), 1220 (CTES); J.G. Seijo \& V. Solís Neffa 3169, 3283 (CTES); J.G. Seijo et al. 2944, 2991, 3858 (CTES); J.M. Silva \& al. 1864 (CTES 282760); L.B. Smith E al. 14533 (SI); J.C. Solomon 7603 (MO 2992215, NY); C. Spegazzini s.n. (BAB 15718); Villa Carenzo 140 (LIL); Wolf \& al. 209 (SI) L.O. Williams 5631 (SI); E.M. Zardini \& R. Britez 52814 (BAB); E.M. Zardini E J. Fernández 45995 (BAB); E.M. Zardini E R. Gamarra 55602 (BAB); E.M. Zardini E L. Guerrero 55322, 55980 (BAB); E.M. Zardini E Velázquez 25650, 26006 (BAB); E.M. Zardini \& M. Vera 53537 (BAB).

Received January $18^{\text {th }} 2011$; accepted May $3^{\text {rd }} 2011$ 